Archives of Agriculture and Environmental Science

\title{
Morphometric relationships between length-weight and length-length and condition factor of four small indigenous fishes from the Payra River, southern Bangladesh
}

\author{
Newton Saha ${ }^{1^{*}}$ (D) , Md. Rahamat Ullah², Md. Samiul Islam² and Md. Belal Hossain ${ }^{2}$ \\ ${ }^{1}$ Department of Fisheries Management, Patuakhali Science and Technology University, Dumki, Patuakhali - 8602, BANGLADESH \\ ${ }^{2}$ Department of Fisheries Biology and Genetics, Patuakhali Science and Technology University, Dumki, Patuakhali - 8602, \\ BANGLADESH \\ "Corresponding author's E-mail: newtonsaha@pstu.ac.bd
}

\section{ARTICLE HISTORY}

Received: 19 May 2019

Revised received: 26 May 2019

Accepted: 06 June 2019

\section{Keywords}

Condition factor

Length-weight relationship

Length-length relationship

Payra River

Small indigenous species (SIS)

\section{ABSTRACT}

The present study describes the length-weight (LWR) relationship, length- length (LLR) relationship, and condition factor $(K)$ of four small indigenous fish species from the Payra River, southern Bangladesh, namely Mastacembelus pancalus, Lepidocephalus guntea, Salmostoma bacaila and Mystus vittatus. A total of 867 specimens, representing 4 species of 4 families used for this study were caught by traditional fishing gear from July to October 2018. Standard length $(\mathrm{SL})$ and total length $(\mathrm{TL})$ for each specimen were measured by digital slide calipers and each body weight (BW) was taken by a digital balance. The allometric coefficient $b$ of the LWR was close to the isometric value $(b=3.078$ and 3.028) in M. pancalus and L. guntea respectively, although it suggested negative allometric growth in $M$. vittatus $(b<3.00)$, whilst positive allometric growth in S. bacaila $(b>3.00)$. All the LWRs were highly significant $(P<$ 0.05 ) and most of the coefficients of determination values were $\geq 0.857$. The results further indicated that the LLRs were highly correlated $\left(r^{2} \geq 0.939 ; P<0.05\right)$. Fulton's condition factor (K) by month basis ranged from 0.52 (in M. pancalus) through 1.89 (in M. vittatus). The results of this study can be very effective for stock assessment of this four species in Payra River as well as in the surrounding ecosystems.

(C)2019 Agriculture and Environmental Science Academy

Citation of this article: Saha, N., Ullah, M.R., Islam, M.S. and Hossain, M.B. (2019). Morphometric relationships between length-weight and length-length and condition factor of four small indigenous fishes from the Payra River, southern Bangladesh. Archives of Agriculture and Environmental Science, 4(2): 230-234, https://dx.doi.org/10.26832/24566632.2019.0402016

\section{INTRODUCTION}

Small indigenous species (SIS) are the species which can grow to a maximum size of $25 \mathrm{~cm}$ or 9 inches in their life cycle (Felts et al., 1996). Among 260 freshwater fishes, 143 species are SIS in Bangladesh (Ali, 1997). The important small indigenous fishes of Bangladesh, including the four species Mastacembelus pancalus (Mastacembelidae), Lepidocephalus guntea (Cobitidae), Salmostoma bacaila (Cyprinidae), and Mystus vittatus (Bagridae), comprise an important component of riverine fisheries in the country's vast river system. Previously abundant in rivers, streams, canals, lakes, reservoirs, ponds and beels, haor and baor swamplands of Bangladesh, India, Nepal and Sri-Lanka (Froese and Pauly, 2011), the populations are in serious decline due to over-exploitation incited by various ecological changes and degradation of their natural habitats. This small indigenous fish species of Bangladesh has a high nutritional value in terms of protein, micronutrients, vitamins and minerals not commonly available in other foods (Ross et al., 2003).

The relationships between length-length and length-weight can be used to determine the well-being of individuals and to determine possible differences between the same species of different area (King, 2007). Moreover, length-length (LLR) and length-weight (LWR) relationships are also important in fisheries management for growth studies among species (Moutopoulos and Stergiou, 2002). The relationship between length-length and length-weight are still rare for most tropical and sub-tropical fish species (Hossain et al., 2009a; Hossain, 
2010). Condition factor $(K)$ is an important biological parameter, which indicates the suitability of a specific water body for growth of fish as well as an index of species average size (Alam et al., 2014). The values of this factor generally depend on physiological features of fish especially maturity, spawning, life-cycle, environmental factors and food availability in a water body (Ujjania et al., 2012; Dan-Kishiya, 2013). To the best of the knowledge there is no previous information on length-length relationship (LLR), length-weight relationship (LWR) and condition factor $(\mathrm{K})$ of most of these species (except Salmostoma bacaila) from the Payra river in Bangladesh. Subsequently, the aim of the present study was carried out to study the lengthweight relationship, length-length relationship, and condition factor of these four species from the Payra River, southern Bangladesh.

\section{MATERIALS AND METHODS}

\section{Study site}

The present study was conducted in the Payra River, southern Bangladesh (Figure 1). The Payra River is a body of running water moving to a lower level in a channel on land in the country of Bangladesh and the river finally fall into the Bay of Bengal by the name of Burishwar River. It's center lies at a latitude of $22^{\circ} 35^{\prime}$ $\mathrm{N}$ and longitude of $90^{\circ} 26^{\prime} \mathrm{E}$ and it has an elevation of 1 meter above sea level. The Payra River is the suitable habitat for fresh water species especially fresh water SIS species are available in this River.

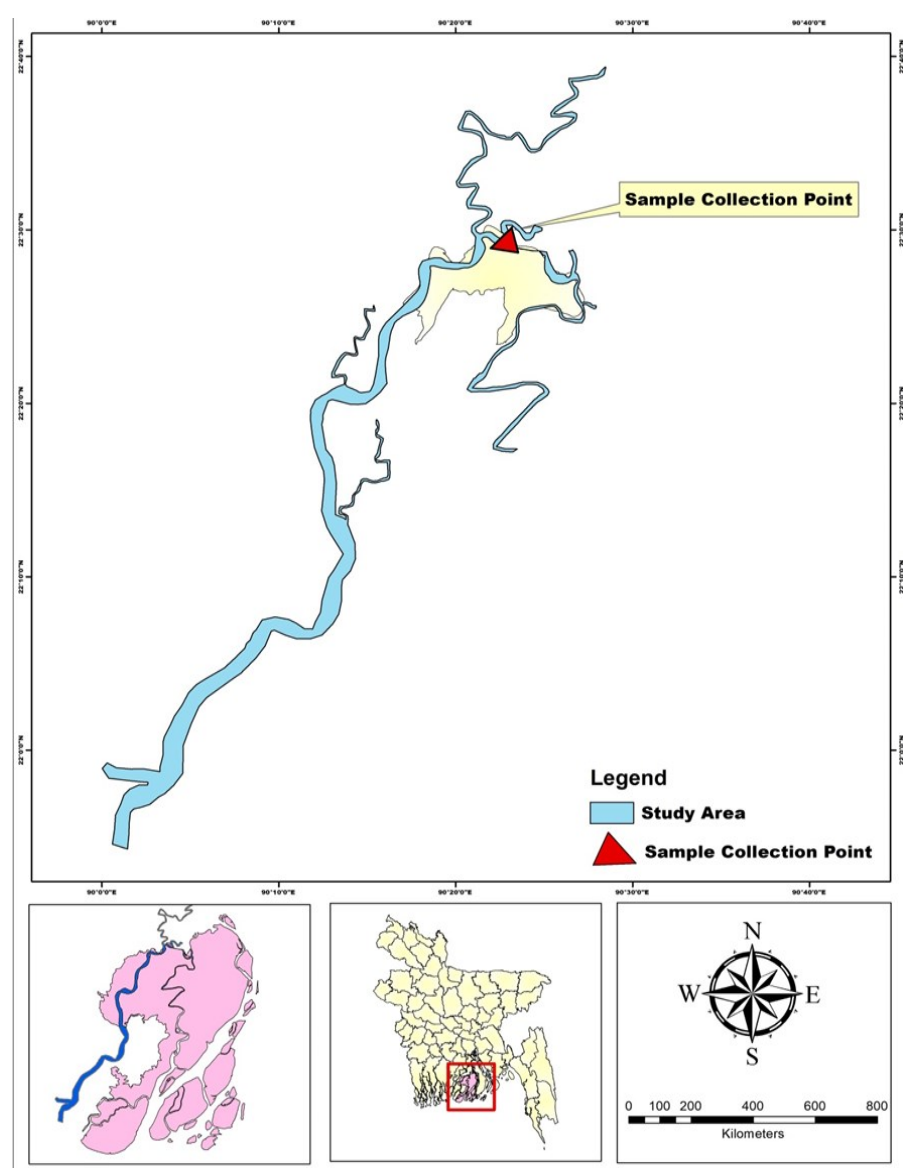

Figure 1. Map of the study site where fish samples were collected.

\section{Collection of fish sample}

Samples were collected using different types of traditional fishing gears including cast net (mesh size 1.0 to $2.0 \mathrm{~cm}$ ), seine net (mesh size 1.5 to $2.5 \mathrm{~cm}$ ) and square lift net (mesh size $\sim 1.0 \mathrm{~cm}$ ) from the Payra River in late July to early October, 2018. During collection of fish, care was taken that individuals of all size groups of every population were proportionately available in the sample. After collection, the specimens were chilled immediately in ice and preserved in $10 \%$ formalin upon arrival at the laboratory to prevent their decomposition.

\section{Preparation of fish sample}

Preserved samples were taken out from the formalin solution and kept on a plastic tray. The tray was placed under running tap water to eliminate dirt, odour of formalin and surplus water from fishes for half an hour. Then fishes were kept in the room temperature for gentle air dry.

\section{Recording of length and weight}

The each individual's standard length (SL) and total length (TL) was measured to the nearest $0.1 \mathrm{~mm}$ using a digital slide caliper (Mitutoyo, CD-6" CSX). The TL was measured from the tip of the snout to the posterior end of the caudal fin. The SL was measured from the tip of the snout to the base of the caudal fin. The individual body weight (BW) was measured using a digital balance (AND, FSH, Korea) to $0.01 \mathrm{~g}$ accuracy. All estimations were done using combined sex. Data were input in on the spread sheet of the computer software, Microsoft Excel.

Determination of length-weight and length-length relationships The length-weight relationship was estimated by linear regression analysis based on natural logarithms: $\ln (W)=\ln (a)+b \ln$ (L), where W is the body weight (BW, g), L is the total length (TL, $\mathrm{cm}$ ), and $\mathrm{a}$ and $\mathrm{b}$ are the regression parameters. Furthermore, $\mathrm{SL}$ vs. TL was estimated by linear regression using combined sex. According to Froese (2006), all extreme outliers were excluded from the analyses. A t-test was applied to determine significant differences from the isometric value ( $b=3.0$ for length-weight relationship and $b=1.0$ for length-length relationship) (Sokal and Rohlf, 1981). Deviation of the $b$ value from the theoretical isometric value indicates either positive ( $b>$ isometric value) or negative $(b<$ isometric value) allometric growth.

\section{Determination of Condition Factor (K)}

Fulton's condition factor $(K)$ was estimated using the equation: $\mathrm{K}=\left(\mathrm{BW} / \mathrm{SL}^{3}\right) \times 100$, for monthly basis.

\section{Data analysis}

The statistical analyses were performed using GRAPHPAD PRISM 8 software (GraphPad Software, Inc., San Diego, CA) and Microsoft Office Excel software (version 2010). Analysis of covariance (ANCOVA) (Zar, 1984) was used to test for significant differences in slopes and intercepts between the relationships. All the statistical analyses were considered significant at $5 \%$ $(P<0.05)$ level of significance. 


\section{RESULTS AND DISCUSSION}

During this study period, a total of 867 specimens belonging to four (4) fish species and four (4) families were collected from the Payra River, southern Bangladesh. Descriptive statistics on the length-weight and length-length measurements and results of other regression analysis are showed in the Tables 1 and 2. In case of body length, the minimum and maximum body length was observed $5.7 \mathrm{~cm}$ and $17.2 \mathrm{~cm}$ from L. guntea and M. pancalus respectively. While the minimum and maximum body weight observed $0.85 \mathrm{~g}$ and $18.00 \mathrm{~g}$ from S. bacaila and M. pancalus, respectively.

The allometric coefficient $b$ of the LWR was close to the isometric value $(b=3.078$ and 3.028$)$ in $M$. pancalus and L. guntea, respectively, although it suggested negative allometric growth in M. vittatus ( $b<3.00$ ), whilst positive allometric growth in $S$. bacaila $(b>3.00)$. All the LWRs were highly significant $(P<$ 0.05 ) and most of the coefficients of determination values were $\geq$ 0.857 . The coefficient of determination $\left(r^{2}\right)$ ranged from 0.857 for M. vittatus to 0.950 for M. pancalus. ANCOVA revealed significant differences among species for the intercepts (a) and slopes (b) of the regression lines $(P<0.05)$. In addition, all LLRs were highly significant $(P<0.05)$ and most of the coefficients of determination values were $\geq 0.939$. The Fulton's condition factors $(K)$ varied monthly showing different pattern for all of the four species (Figure 2). Monthly condition factor ranged from 0.52 (in $M$. pancalus) through 1.89 (in M. vittatus). The lowest and highest $\mathrm{K}$ value ranges were found 0.52-0.58 in M. pancalus and 1.85-1.89 in $M$. vittatus, respectively from July to October.

The length-weight relationship (LWR) can be resulting from the length and weight measurements of the same fishes throughout their lives or from a sample of fish taken at a particular time (Wootton, 1990). The values of $a$ and $b$ for the four species in this study were within the limits reported by Froese (2006), although these parameters varied significantly among the species. The estimated $b$ value for $S$. bacaila was found to be higher compared to the study of Ahamed et al. (2018) from the Payra River. In the present study, the calculated $b$ value of the
LWRs indicated negative allometric growth in M. vittatus $(b<$ 3.00) and isometric growth in L. guntea $(b=3.00)$. On the other hands, Hossain et al. (2009b) reported isometric growth for both of the two species M. vittatus and L. guntea from the Ganges, Bangladesh. In the present study, the $b$ value of the LWRs indicated isometric growth in M. pancalus $(b=3.00)$, while Narejo et al. (2003) reported negative allometric growth in M. pancalus $(b<3.00)$ from Mymensingh, Bangladesh. So, none of the existing results were similar with the present study, which might be due to the uses of different types of fishing gears with different mesh sizes. Consequently, a standardized sampling procedure is needed to compare the results of LWRs from the different studies. Another reason of these variations may be the preservation techniques of the fish samples (Tesch, 1971) as the present study used formalin (10\% formalin solution) preserved samples. Therefore, further study is needed using fresh samples to compare the results and deserve to be explored in future research.

The condition factor is an important index reflecting interaction between biotic and abiotic factors in the physiological conditions of fishes. Hence, the condition factor may vary among fish species in different locations (Blackwell et al., 2000). This factor is also used as an index of growth and feeding intensity (Seher and Suleyman, 2012). Condition factors of $\geq 1$ indicate a good level of feeding and proper environmental conditions (Ujjania et al., 2012). Based on the results, it was $<1$ for M. pancalus and $S$. bacaila showing no proper environmental conditions of habitat for this two species in Payra River, whereas, $\mathrm{K}$ values of the rest of two species were $>1$ showing suitable conditions of this river for them.

Furthermore, LWR parameters ( $a$ and $b$ ) and the " $K$ " value of the fish have been reported to be influenced by many factors such as feeding intensity, availability of food, fish size, age, sex, season, stage of maturation, fullness of the gut, degree of muscular development, the amount of reserved fat and life history (Bagenal and Tesch, 1978; Ujjania et al., 2012; Gupta and Banerjee, 2015). None of the above - mentioned effective factors on LWRs and $K$ in the studied fishes have been considered in the present study.

Table 1. Descriptive statistics and estimated parameters of length-weight relationships $\left(B W=a \times T L^{b}\right)$ for four fish species from the Payra River, southern Bangladesh, July 2018 to October 2018.

\begin{tabular}{|c|c|c|c|c|c|c|c|c|c|c|}
\hline \multirow[t]{2}{*}{ Species } & \multirow[t]{2}{*}{$\mathrm{n}$} & \multicolumn{2}{|c|}{$\mathrm{TL}(\mathrm{cm})$} & \multicolumn{2}{|c|}{ BW (g) } & \multicolumn{2}{|c|}{$\begin{array}{l}\text { Regression } \\
\text { parameters }\end{array}$} & \multirow[t]{2}{*}{$95 \% \mathrm{Cl}$ of a } & \multirow[t]{2}{*}{$95 \% \mathrm{Cl}$ of $\mathrm{b}$} & \multirow[t]{2}{*}{$r^{2}$} \\
\hline & & Min & Max & Min & Max & a & b & & & \\
\hline $\begin{array}{l}\text { M. pancalus } \\
\text { (Mastacembelidae) }\end{array}$ & 200 & 6.6 & 17.2 & 1.07 & 18.00 & -2.425 & 3.078 & -2.5315 to -2.3177 & 2.9724 to 3.1842 & 0.950 \\
\hline $\begin{array}{l}\text { L.guntea } \\
\text { (Cobitidae) }\end{array}$ & 167 & 5.7 & 9.7 & 1.31 & 7.84 & -2.104 & 3.028 & -2.2641 to -1.9435 & 2.8464 to 3.2090 & 0.882 \\
\hline $\begin{array}{l}\text { S. bacaila } \\
\text { (Cyprinidae) }\end{array}$ & 300 & 5.1 & 11.3 & 0.85 & 9.39 & -2.370 & 3.115 & -2.4691 to -2.2703 & 3.0058 to 3.2248 & 0.923 \\
\hline $\begin{array}{l}\text { M. vittatus } \\
\text { (Bagridae) }\end{array}$ & 200 & 6.1 & 11.5 & 2.18 & 13.04 & -2.023 & 2.957 & -2.1847 to -1.8603 & 2.7762 to 3.1372 & 0.857 \\
\hline
\end{tabular}

$\mathrm{n}$, sample size; TL, total length; BW, body weight; Min, minimum; Max, maximum; a and b, parameters of the length-weight relationship; $\mathrm{Cl}$, confidence interval; $r^{2}$, coefficient of determination. 
Table 2. Descriptive statistics and estimated parameters of length-length relationships for four fish species from the Payra River, southern Bangladesh, July 2018 to October 2018.

\begin{tabular}{|c|c|c|c|c|c|c|c|}
\hline \multirow[t]{2}{*}{ Species } & \multirow[t]{2}{*}{$\mathrm{n}$} & \multirow[t]{2}{*}{ Equation } & \multicolumn{2}{|c|}{$\begin{array}{l}\text { Regression } \\
\text { parameters }\end{array}$} & \multirow[t]{2}{*}{$95 \% \mathrm{Cl}$ of a } & \multirow[t]{2}{*}{$95 \% \mathrm{Cl}$ of $\mathrm{b}$} & \multirow[t]{2}{*}{$r^{2}$} \\
\hline & & & a & b & & & \\
\hline $\begin{array}{l}\text { M. pancalus } \\
\text { (Mastacembelidae) }\end{array}$ & 200 & $\mathrm{TL}=\mathrm{a}+\mathrm{b} . \mathrm{SL}$ & 0.040 & 0.987 & 0.0266 to 0.0540 & 0.9733 to 1.0010 & 0.991 \\
\hline L. guntea (Cobitidae) & 167 & $T L=a+b \cdot S L$ & 0.136 & 0.929 & 0.1068 to 0.1644 & 0.8863 to 0.9573 & 0.948 \\
\hline S. bacaila (Cyprinidae) & 300 & $T L=a+b \cdot S L$ & 0.125 & 0.943 & 0.1078 to 0.1422 & 0.9219 to 0.9635 & 0.968 \\
\hline M. vittatus (Bagridae) & 200 & $T L=a+b . S L$ & 0.134 & 0.970 & 0.1053 to 0.1633 & 0.9328 to 1.0068 & 0.939 \\
\hline
\end{tabular}

$\mathrm{n}$, sample size; $\mathrm{a}$, intercept; $\mathrm{b}$, slope; $\mathrm{TL}$, total length; $\mathrm{Cl}$, confidence interval; $\mathrm{r}^{2}$, coefficient of determination.

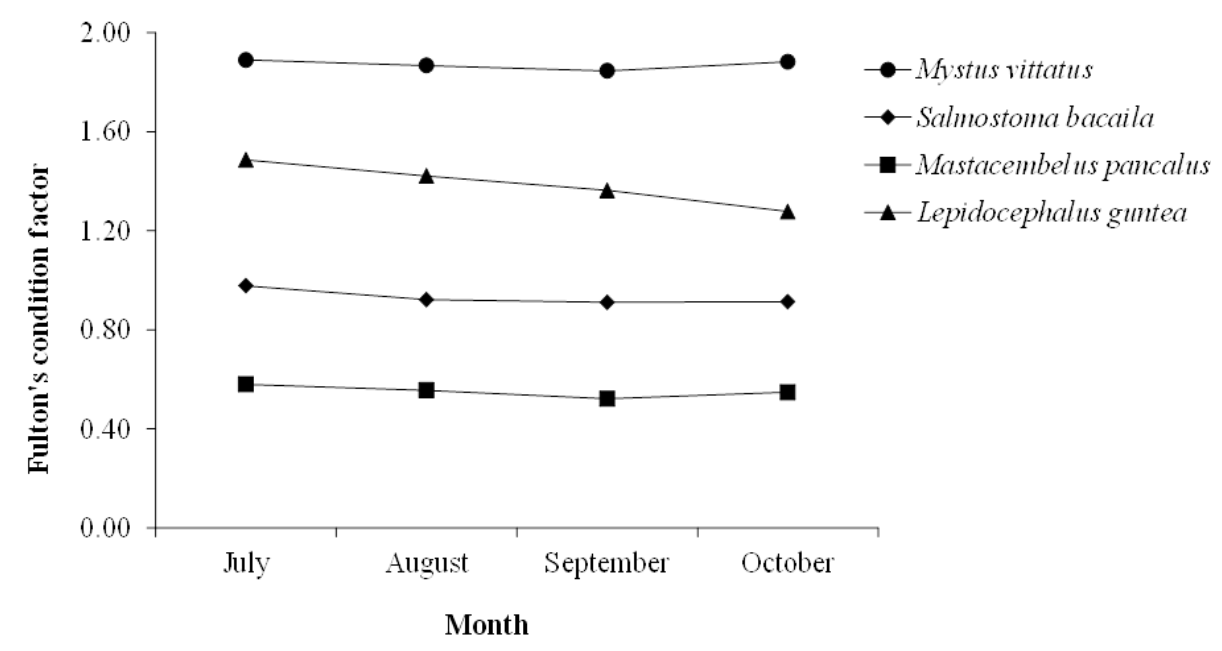

Figure 2. Temporal trends in the $\mathrm{K}$ - values of fish samples examined.

\section{Conclusion}

Based on the results, all the LWRs were highly significant $(\mathrm{P}<$ 0.05 ) and most of the coefficients of determination values were $\geq 0.857$. The results further indicated that the LLRs were highly correlated $\left(r^{2} \geq 0.939 ; P<0.05\right)$. The value of $K$ was $<1$ for $M$. pancalus and $S$. bacaila showing no proper environmental conditions of habitat for this two species in Payra River, whereas, $\mathrm{K}$ values of the rest of two species were $>1$ showing suitable conditions of this river for them. These results will be helpful for stock assessment of these fishes in the Payra River and the surrounding ecosystem and also would be an important baseline for future studies. However, further and more detailed researches are necessary for future assessment.

Conflict of interest: The authors declare there are no conflicts of interest.

Open Access: This is an open access article distributed under the terms of the Creative Commons Attribution 4.0 License, which permits unrestricted use, distribution, and reproduction in any medium, provided the original author(s) if the sources are credited.

\section{REFERENCES}

Ahamed, F., Saha, N., Nishat, M.A., Biswas, M.K., Sultana, M., Khatun, M.S., Ahmed, Z.F., Hossain, M.Y. and Ohtomi, J. (2018). Length-weight and length-length relationships of three small indigenous fishes from the Payra River, southern Bangladesh. Journal of Applied Ichthyology, 34(3): 777-779, https://doi.org/10.1111/jai.13642

Alam, M.M., Rahman, M.T. and Parween, S. (2014). Morphometric characters and condition factors of five freshwater fishes from Pagla River of Bangladesh. International Journal of Aquatic Biology, 2(1):14-19, https://doi.org/10.22034/ijab.v2i1.18

Ali, M.Y. (1997). Small indigenous fish species culture in Bangladesh, Proceedings of national workshop on small indigenous fish culture in Bangladesh, IFADEP-SP 2, Dhaka, Bangladesh.

Bagenal, T.B. and Tesch, F.W. (1978). Age and growth. In: T.B. Bagenal (ed.). Methods of assessment of fish production in fresh waters, Oxford Blackwell Scientific Publication. pp. 101-136.

Blackwell, B.G., Brown, M.L. and Willis, D.W. (2000). Relative weight $\left(\mathrm{W}_{\mathrm{r}}\right)$ status and current use in fisheries assessment and management. Reviews in Fisheries Science, 8:1-44.

Dan-Kishiya, A.S. (2013). Length-weight relationship and condition factor of five fish species from a tropical water supply reservoir in Abuja, Nigeria. American Journal of Research Communication, 1(9): 175-187.

Felts, R.A., Rajts, F. and Akhteruzzaman, M. (1996). Small indigenous fish species culture in Bangladesh. Technical brief. IFADEP Sub-project- 2. Development of Inland Fisheries. pp. 41.

Froese, R. (2006). Cube law, condition factor and weight-length relationships: history, meta-analysis and recommendations. Journal of Applied Ichthyology, 22(4): 241-25, https://doi.org/10.1111/j.1439-0426.2006.00805.x

Froese, R. and Pauly, D. (Eds), (2011). Fish Base 2011. World Wide Web electronic publication. Retrieved from http://www.fishbase.org

Gupta, S. and Banerjee, S. (2015). Length-weight relationship of Mystus tengara (Ham.-Buch., 1822), a freshwater catfish of Indian subcontinent. International Journal of Aquatic Biology, 3(2):114-118.

Hossain, M.Y. (2010). Morphometric relationships of length-weight and lengthlength of four cyprinid small indigenous fish species from the Padma River (NW Bangladesh). Turkish Journal of Fisheries and Aquatic Sciences, 10: 131-134

Hossain, M.Y., Ohtomi, J., Ahmed, Z.F. (2009a). Morphometric, meristic characteristics and conservation of the threatened fish, Puntius sarana (Hamilton 
1822) (Cyprinidae) in the Ganges River, north western Bangladesh. Turkish Journal of Fisheries and Aquatic Science, 9: 223-225.

Hossain, M.Y., Jasmine, S., Ibrahim, A.H M., Ahmed, Z.F., Rahman, M.M. and Ohtomi, J. (2009b). Length-weight and length-length relationships of 10 small fish species from the Ganges, Bangladesh. Journal of Applied Ichthyology, 25(1): 117-119, https://doi.org/10.1111/j.1439-0426.2008.01168.x

King, M. (2007). Fisheries biology, assessment and management. Second Edition. Blackwell Scientific Publications, Oxford: 1-381.

Moutopoulos, D.K. and Stergiou, K.I. (2002). Length-weight and length-length relationships of fish species from Aegean Sea (Greece). Journal of Applied Ichthyology, 18: 200-203.

Narejo, N.T., Rahamatullah, S.M. and Rashid, M.M. (2003). Length-weight relationship and relative condition factor $(\mathrm{Kn})$ of freshwater spiny eel, Mastacembalus armatus (Lacepede) from Mymensingh, Bangladesh. Indian Journal of Fisheries, 50(1): 81-87.

Ross, N., Islam, M. and Thilsted, S.H. (2003). Small indigenous fish species in
Bangladesh: contribution to vitamin A, calcium and iron intakes. International Journal of Food Sciences and Nutrition, 133: 4021-4026.

Seher, D. and Suleyman, C.I. (2012). Condition factors of seven cyprinid fish species from Çamligöze Dam Lake on central Anatolia, Turkey. African Journal of Agricultural Research, 7(31): 4460-4464.

Sokal, R.R. and Rohlf, F.J. (1981). Biometry. 2nd ed. New York: W.H. Freeman and Company.

Tesch, F.W. (1971). Age and growth. In W. E. Ricker (Ed.), Methods for assessment of fish production in fresh waters. Oxford: Blackwell Scientific, pp. 99-130.

Ujjania, N.C., Kohli, M.P.S. and Sharma, L.L. (2012). Length-weight relationship and condition factors of Indian major carps (Catla catla, Labeo rohita and Cirrhinus mrigala) in Mahi Bajaj Sagar, India. Research Journal of Biology, 2(1): 30-36.

Wootton, R.J. (1998). Ecology of teleost fishes. 2nd edition. Chapman and Hall. Upper Saddle River, New Jersey, USA. 24.

Zar, J.H. (1984). Biostatistical Analysis. 2nd Edn., Prentice-Hall Inc., Englewood Cliffs, New Jersey, USA. 